\title{
BIBLIOGRAFIA PRAC Prof. Dr JANINY BIENIARZÓWNY ZA LATA 1986-1993 ${ }^{1}$
}

Zestawił Ks. Andrzej Bruździński

1986

1. Profesor doktor Krystyna Pieradzka (1908-1986). „Rocznik Krakowski”. T. 52:1986, s. 151-155.

2. Krakowoski handel ksiqżkq wo drugiej połorvie XVII w. W: Historia ksiqżki i jej funkcji społecznej. Cz. 2: Wybór tekstów naukowych dla studentów bibliotekoznawstwa i informacji naukowej. Pod red. W. Szelińskiej i M. Konopki. Kraków 1986, s. $34-54$.

3. Rajman (Rayman, Reyman) Kasper, (zm. ok, 1600), introligator krakowski. W: Polski Słownik Biograficzny (dalej: PSB). T. 30, s. 485-486.

4. Rambieski (Rąieski) Wawrzynice (zm. 1570), kupiec i raja krakowski. W: Tamże, s. 541.

5. Rapp (Rab, Rabb, Rap) Stanistaw (zm. 1631) kupiec i rajca krakowski. W: Tamże, s. 585-586.

1988

6. Odrodzenie życia religijnego w Krakowie na przetomie XVI i XVII w. W: Dialog Kościoła $z$ kulturq. T. 2: Materiały z VI i VII Tygodnia Kultury Chrześcijańskiej w Krakowie. Pod red. S. Misińca, Kraków 1988, s. 168-174.

1 "Bibliografię prac prof. dr Janiny Bieniarzówny za lata 1946-1986" zestawil Jan Szpak. Opublikowana została w pracy zbiorowej pod redakcja Jana M. Maleckiego pt. „Z przeszlości Krakowa". Warszawa-Kraków 1989, s. 7-23. - Opuszczono w niej artykul: Św. Teresa w kulturze polskiej XVII i XVIII wieku. W: „Karmel”, [R.2]: 1982, z. 2 s. 3-10. 


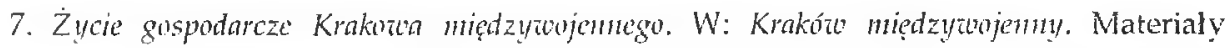
sesji naukowej z okazji Dni Krakowa w roku 1985. Pod red. J.M. Małeckiego. Kraków 1988, s. 23-29.

8. Studenci-Żydzi na wydziale lekarskim UI wo pieruszej połowic XIX wieku. "Krzysztofory" T. 15:1988, s. 33-39.

9. Reismoller (Reismoler, Reismoeler, Raiszmolner) Piotr (1 pot. XV] w.) ksieggarz krakowski. W: PSB. T. 31, s. 33.

10. Rejnekier (Reineker, Rayneker) Jakub (zm. 1701), lekarz i rajca krakowoski. W: Tamże, s. 59 .

11. Romnnowic Jan (zm. 1678), prawnik i rajca krakowski, sekretarz królewski. W: Tamże, 5. 588-589.

12. Romatowski Waworzyniec (zm. 1570), ztotnik, fawnik sqdu wyższego prawa magdeburskiego na zamku krakowskim. W: Tamże, s. 623.

13. Romer (Remer, Rymer) Bartłomiej (zm. między 1556 a 1557), kupicc i rajca krakouski. W: Tamże, s. 632.

\section{9}

14. Ksigdz Jakub Janidto - woybitny przedstawiciel profesury krakowskiej XVII-shulecia. „Folia Historica Cracoviensia" (dalej: FHC) T. 1:1989, s. 23-29.

15. Ronenberg (Romnenberg) Abralam (ok. 1570-1625), aptekarz i raja krakowski. W: PSB T. 32, s. 14-15.

16. Roszkowvic (Roscius, Roszkozvicz) lakub (1567-1618), lekarz i rajca kraknzuski. W: Tamże, s. 258.

17. Różyc Jon (zm. 1689), mprtekarz i rajon krakoroski. W: Tamże, s. 510

18. Słowo wostępne.. W: FHC T. 1:1989 s. 5-6.

19. Opieka spoteczna w Krakowie w latach wojny. Z dziejów KBK. W: Rola Krakowa w dziejach narodu. T. 8: Kraków w czasie l wojny świntowej. Materiały sesji naukowej z okazji Dni Krakowa w roku 1988. Pod red. J.M. Maleckiego. Kraków 1990, s. 97-111.

20. Stowo zostępne. W: W. Murawiec, S. Piech. $Z$ dziejów formacji $i$ ksztatcenia duchowieristzua katolickiego wo Polsce. Kraków 1990, 5. 5-6.

21. Uniwersyteccy pronotorzy kultu śzo. Jann Kantego. „Biuletyn Papieskiej Akademii Teologicznej w Krakowie". R. 9:1990/91, s. 48-51.

1991

22. Postać św. Jana Kantego w świadoności społecznej ludzi XVII wieku. W: Św. Jan Kanty. W sześcsetnq rocznicę urodzin 1390-1990. Pod red. R.M. Zawadzkiego. Kraków 1991 , s. $87-102$. 
23. Handol żydowoski w stuleciu upadku Krakowa. W: Żydzi w dninej Rzeczypospolitej. Materialy w konferencji "Autonomia Żydów w Rzeczypospolitej szlacheckiej”. Międzywydzialowy Zakład Historii i Kultury Żydow w Polsce. Uniwersytet Jagielloński 22-26 IX 1986 Pod red. A. Linka-Lenczewskiego, T. Polańskiego. Wrocław-Warszawa-Kraków 1991, s. 226-236.

24. Laudatio [doktorat honoris causa ks. prof. P. Rabikauskasa Sl]. „Biuletyn Papieskiej Akademii Teologicznej". R. 10:1991/92, s. 39-42.

\section{2}

25. Kraków - niełatwe miasto trudnych ludzi. W: Józef Sebastian Pelczar, profesor Unitoersytetu Ingielloniskiego, biskup przemyski i założyciel Słıżebnic Najświętszego Serca Jezusowego wo przedednin bentyfikacji. Sesja naukowa 26 i 27 kwietnia 1991. Pod red. F. Sankowskiej. Kraków 1992, s. 25-36.

26. Wojciech Maria Bartel (1923-1992). "Rocznik Krakowski". T. 58:1992, s. 167-169.

27. The Role of Jews in the Polish foreign Trade 1648-1764. W: The Jews in Poland. Pod red. A.K. Palucha. T. 1. Kraków 1992, s. 101-109.

28. Krakowskie targi w dawnych wiekach. W: Krakózw - przestrzenie kulturowe. Kraków 1993 , s. $51-62$.

29. Salawa Anicla (1881-1922), bfogostawiona. W: PSB T. 34, s. 356 n.

30. Salomon zz. Wtochowiczem (zm. ok. 1650). W: Tamże. s. $374 \mathrm{n}$.

31. Salomon Stanistaw h. Łabędź (zm. 1546). W: Tamże, s. $384 \mathrm{n}$.

32. Samuel de Sacerdotibus Patavimus (zm. 1648). W: Tamże, s. 439. 